
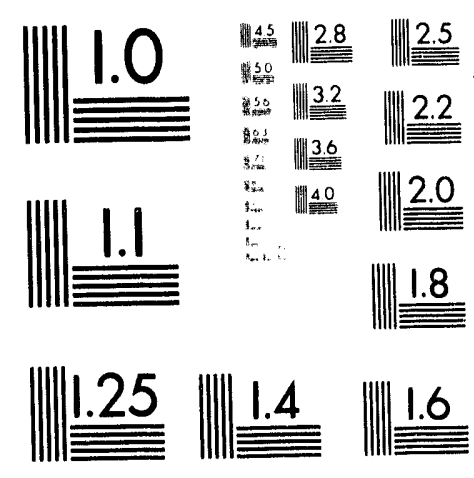

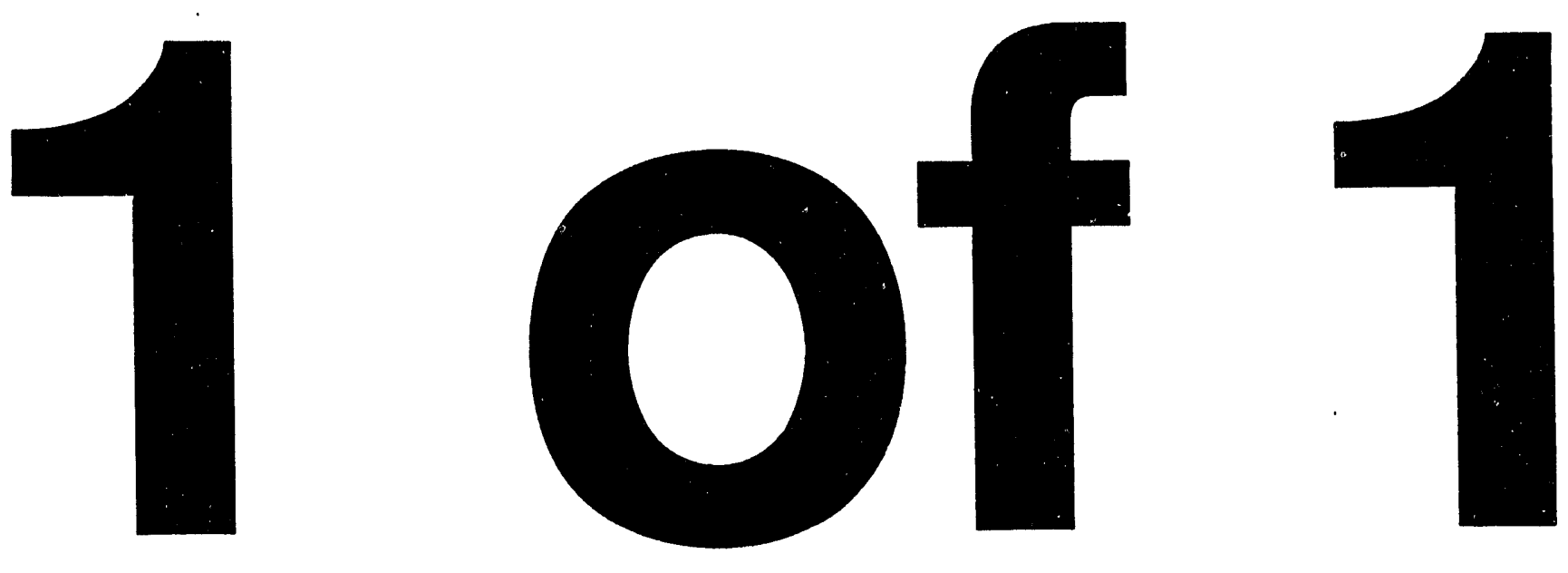


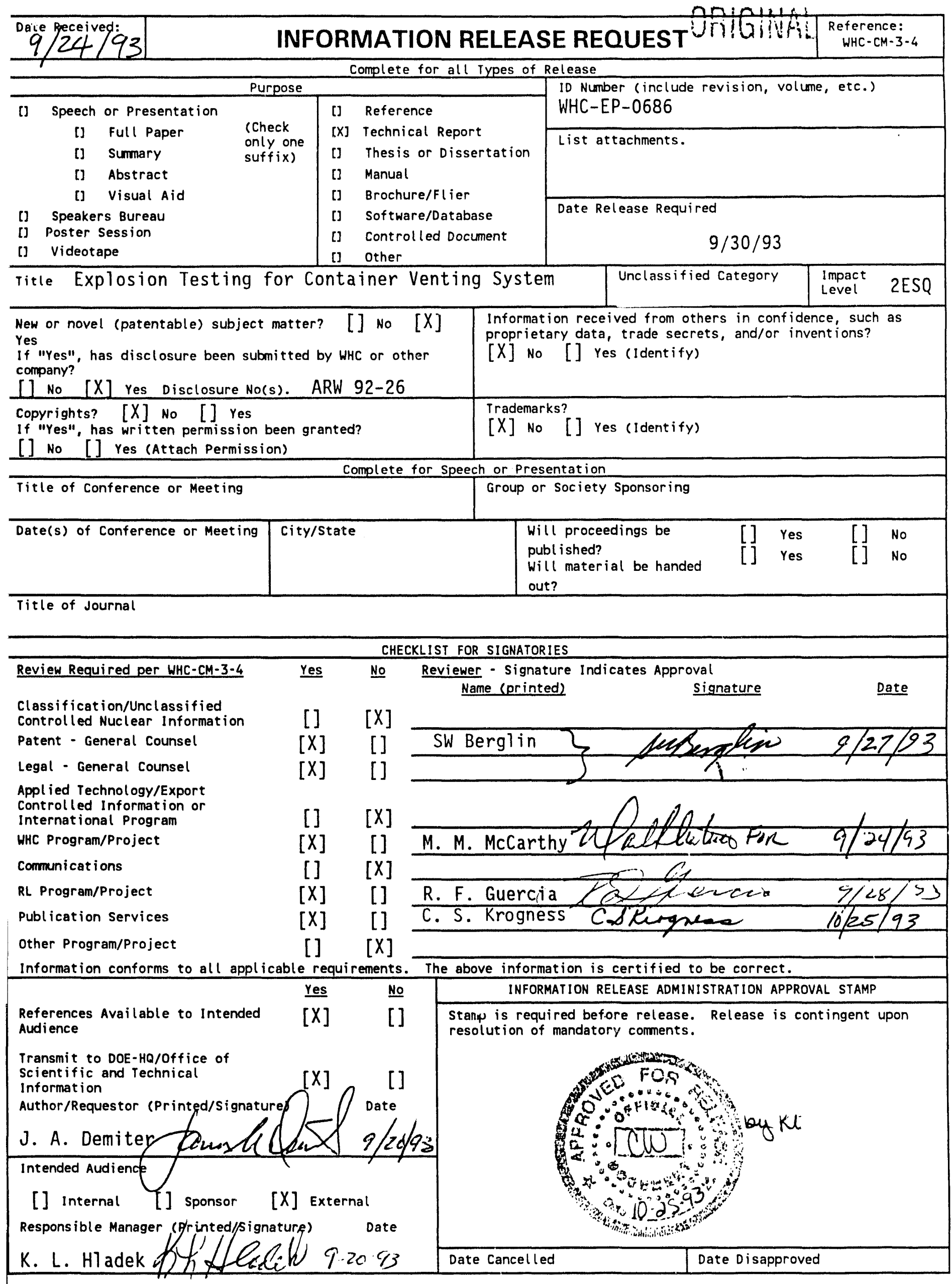


WHC-EP-0686

\title{
Explosion Testing for the Container Venting System
}

\author{
K. L. Cashdollar \\ G. M. Green \\ R. A. Thomas \\ U.S. Department of the Interior \\ J. A. Demiter \\ Westinghouse Hanford Company \\ Date Published \\ October 1993
}

Prepared for the U.S. Department of Energy Office of Environmental Restoration and Waste Management

\footnotetext{
(2) Westinghouse P.O. Box 1970 Hanford Company Richland, Washington 99352

Hanford Operations and Engineering Contractor for the

U.S. Department of Energy under Contract DE-AC06-87RL10930
}

Approved for Public Release

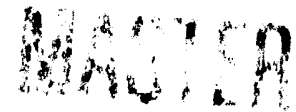


WHC-EP-0686

Document Title: Explosion Testing for the Container Venting system Solid Waste Programs

Prepared by:
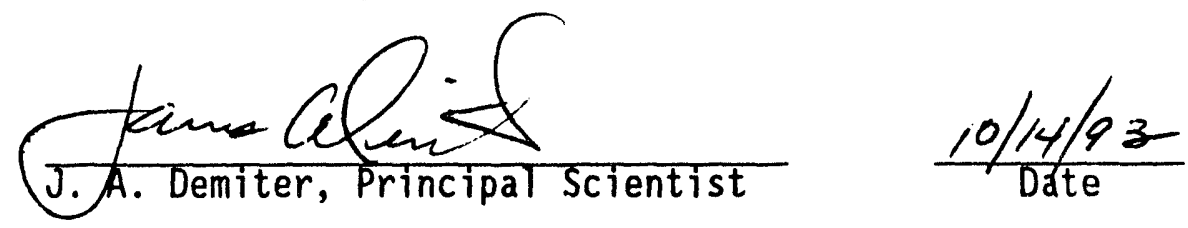

Reviewed by:

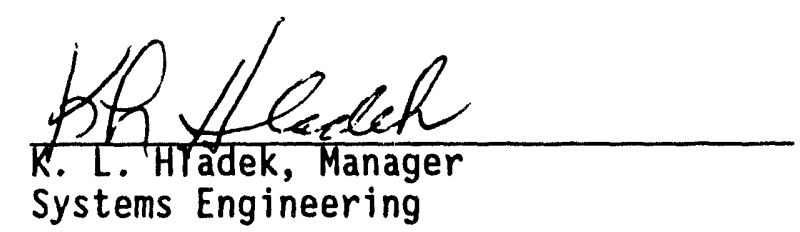

$\frac{10-14-93}{\text { Date }}$

Approved by: $\quad$ m.m.mecourthex

$\frac{16 \text { Set } 93}{\text { Date }}$ Solid Waste Programs 


\section{ACKNOWLEDGEMENTS}

The authors wish to acknowledge the financial support of the U.S. Department of Energy through Westinghouse Hanford Company for this research. The work was performed under Memorandum of Agreement 14-09-0050-3605 between the U.S. Bureau of Mines and Westinghouse Hanford Company. We also thank C. W. Ganoe and $C$. E. Lucci of the Pittsburgh Research Center for their assistance with the operation of the infrared video camera. 


\title{
EXPLOSION TESTING FOR THE CONTAINER VENTING SYSTEN
}

\begin{abstract}
As part of the study of the hazards of inspecting nuclear waste stored at the Hanford Site, the U.S. Department of Energy and Westinghouse Hanford Company have developed a container venting system to sample the gases that may be present in various metal drums and other containers. In support of this work, the U.S. Bureau of Mines has studied the probability of ignition while drilling into drums and other containers that may contain flammable gas mixtures. The Westinghouse Hanford Company drilling procedure was simulated by tests conducted in the Bureau's 8-liter chamber, using the same type of pneumatic drill that will be used at the Hanford Site. There were no ignitions of near-stoichiometric hydrogen-air or methane-air mixtures during the drilling tests. The temperatures of the drill bits and lids were measured by an infrared video camera during the drilling tests. These measured temperatures are significantly lower than the $-500{ }^{\circ} \mathrm{C}$ autoignition temperature of uniformly heated hydrogen-air or the ${ }^{\circ} 600^{\circ} \mathrm{C}$ autoignition temperature of uniformly heated methane-air. The temperatures are substantially lower than the $750{ }^{\circ} \mathrm{C}$ ignition temperature of hydrogen-air and $1,220^{\circ} \mathrm{C}$ temperature of methane-air when heated by a 1-mm-diameter wire.
\end{abstract}




\section{TABLE OF CONTENTS}

1.0 INTRODUCTION . . . . . . . . . . . . . . . . . . 1

2.0 EXPERIMENTAL EQUIPMENT AND INSTRUMENTATION .............. 1

2.1 TEST CHAMBER . . . . . . . . . . . . . . . . . . 1

2.2 VIDEO CAMERAS ....................... 3

3.0 EXPERIMENTAL PROCEDURES ...................... . . 4

4.0 FLAMMABILITY AND IGNITABILITY OF HYDROGEN AND METHANE IN AIR . . . 5

5.0 EXPERIMENTAL DATA . . . . . . . . . . . . . . . . . 6

5.1 FLAMMABILITY TESTS IN CLOSED OR VENTED CHAMBER . . . . . . . . . . 6

5.2 DRILLING TESTS ...................... 6

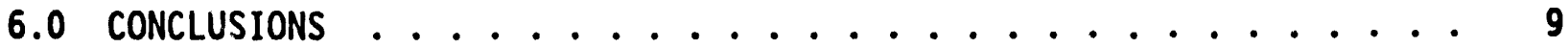

7.0 REFERENCES ......................... 9

\section{APPENDIXES}

A. Flammability Tests in 8-L Chamber, With Electric Spark Ignition. . . A-1

B. Tests of Drilling Into 8-L Chamber Containing Flammable Gas.................... B-1

\section{FIGURE}

1. Schematic of 8-Liter Test Chamber and Pneumatic Drill. . . . . . . 2 
WHC-EP-0686

\section{LIST OF TERMS}

$A / D$ analog to digital

$\mathrm{CH}_{\text {m }}$ methane

CVS Container Venting System

DOE U.S. Department of Energy

$\mathrm{H}_{3}$ hydrogen

IR infrared

PC personal computer

TiN titanium nitride

WHC Westinghouse Hanford Company 
WHC-EP-0686

\subsection{INTRODUCTION}

The Hanford Site in the state of Washington has been a defense production facility for the U.S. Department of Energy (DOE) and its predecessors for many years. The Site is presently managed by Westinghouse Hanford Company (WHC). Substantial solid waste volumes were generated during defense material production. Some of these wastes were placed in metal drums and other containers and stored in underground trenches covered with earth. Hydrogen (or other flammable gases) could be present in the waste drums, resulting from organic decay and/or radiolysis. The DOE and WHC are committed to waste cleanup and characterization, placing worker safety and environment protection paramount during this effort. Therefore, WHC has designed special retrieval equipment to move the waste drums from underground storage to an aboveground storage and inspection facility. A key piece of retrieval equipment is the Container Venting System (CVS). This system features drum piercing, drum-gas sampling/purging capability, drum lifting, and filter installation. Key components are a pneumatic drill (Quackenbush Model 158QGDABV-S150) equipped with a 5/16-in. titanium nitride- (TiN-) coated drill bit that penetrates the waste drum lid.

As part of the DOE and WHC study of the hazards of nuclear waste cleanup at the Hanford Site, the U.S. Bureau of Mines was contracted to determine whether ignition might occur while using the CVS to drill into a container filled with a flammable gas mixture. This Bureau research was not meant to be a comprehensive safety evaluation of all aspects of the CVS. The Bureau only evaluated the question of whether drilling through drum lids could ignite flammable hydrogen-air or methane-air mixtures. The results of this study will be used by the DOE and WHC as part of the overall safety evaluation of the CVS.

The particular gases tested were near-stoichiometric mixtures of hydrogen-air or methane-air. First, the flammability of these gases was studied by using a spark ignition source. Then the question of whether or not the CVS could ignite the flammable gas mixtures was investigated. The WHC drilling procedure was simulated by tests conducted with the Bureau's 8-L chamber. The Quackenbush pneumatic drill was used to drill through test coupons (1ids of various thickness). An infrared video system was used to measure temperatures of the test coupons and drill bits during drilling.

\subsection{EXPERIMENTAL EQUIPMENT AND INSTRUMENTATION}

\subsection{TEST CHAMBER}

The instrumentation and test procedures used for this project were similar to those used for the previous research project that the Bureau conducted for the DOE and WHC (Cashdollar et al. 1992). The ignitability tests were conducted in an 8-L chamber (Figure 1). Instrumentation for

\footnotetext{
${ }^{1} T$ The Quackenbush drill is a trademark of the Industrial Tool Division, Dresser Industries, Inc.
} 
Figure 1. Schematic of 8-Liter Test Chamber and Pneumatic Drill.

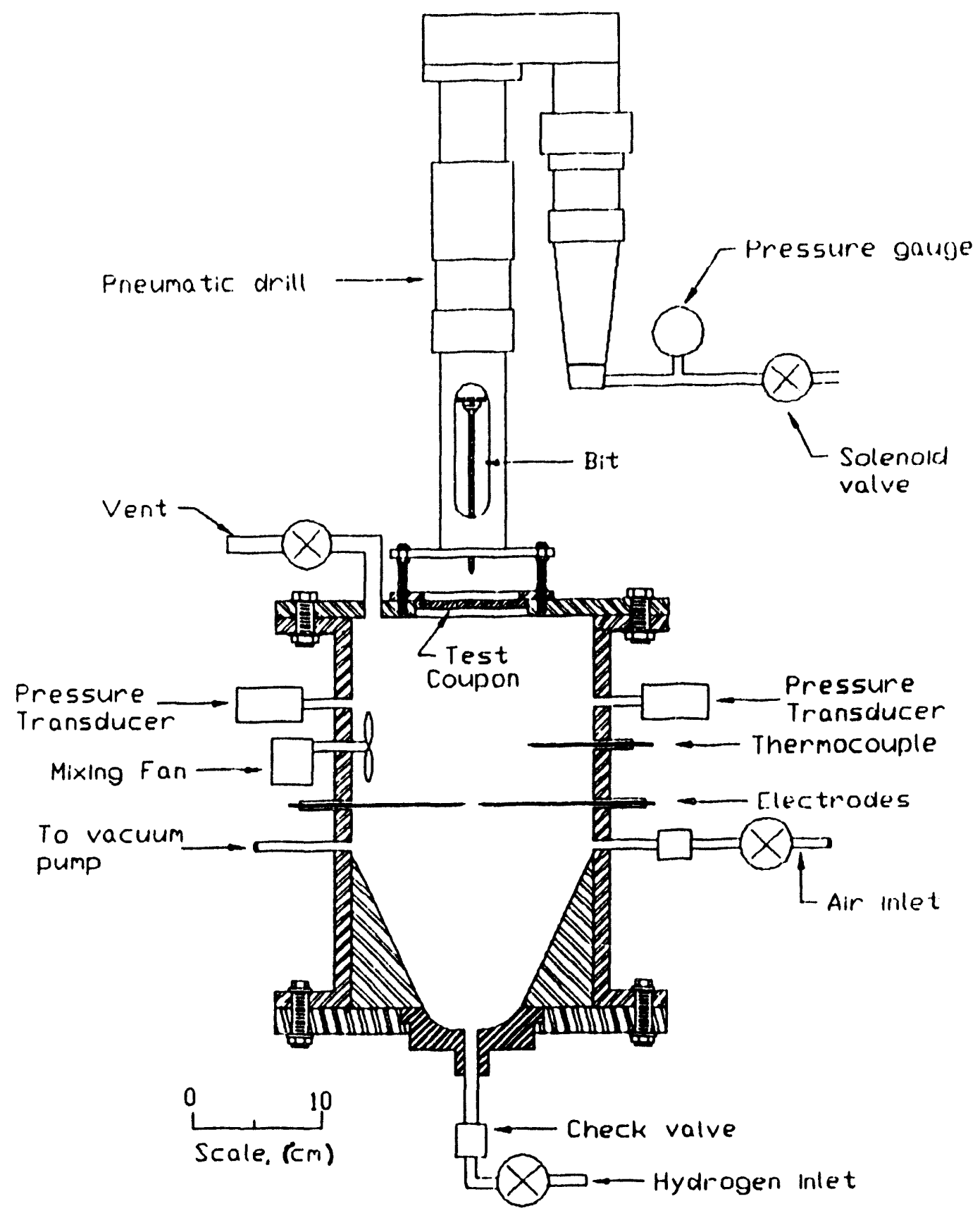


the chamber included two strain-gauge pressure transducers and a 320- $\mu \mathrm{m}$ (12.5-mil) Type $K$ thermocouple, which was used to monitor the chamber gas temperature. The Quackenbush pneumatic drill was mounted to the top fiange of the chamber, as shown in Figure 1. The test coupons, mounted below the drill, were $76 \mathrm{~mm}$ ( 3 in.) in diameter and were made from 1.5-mm- (16-gauge-) thick steel drum lids or $6.5-\mathrm{mm}(t-i n$.$) carbon steel plates. An internal fan,$ mounted through the side wail of the chamber, was used to mix the gases. The two spark electrodes could be used to ignite the gas mixtures for the flammability tests.

The data from the pressure transducers were recorded with a personal computer (PC) equipped with a high-speed analog-to-digital (A/D) board. $A$ Bureau-designed computer software program converted the sensor data to engineering units and plotted the results versus time. These plots were used to obtain the maximum pressure and maximum rate of pressure rise values. Data from the two pressure transducers were compared and averaged. The calibrations of the two pressure transducers were checked daily using the internal calibration resistors provided by the manufacturers. The data from the tests were permanently stored on both the PC hard disk and on floppy disks.

\subsection{VIDEO CAMERAS}

A regular (visible light) video camera and an infrared (IR) video camera observed the 8-L chamber flammability and ignitability tests. Each video camera observed the test coupon from above at an angle of about 45 degrees. The regular video camera gave a visual image of the drilling process and would observe any possible sparks or flames. The IR video system (Hughes Probeye Mode 17300 ) was used to record the temperature changes of the test coupon and drill bit during the drilling process. The IR video measures radiation at wavelengths of about 2 to $5 \mathrm{\mu m}$. This radiation is then converted to a temperature display at 30 frames per second on the video monitor. The IR video, therefore, provides a false color image of the drill assembly, test coupon, and 8-L chamber during each test. The colors are correlated to temperature through a temperature color key at the right side of the video image. The maximum temperature in the field of view can be obtained after the test through a frame-by-frame evaluation of the IR video recording.

The IR video system was calibrated using both a blackbody reference source and a hotplate. The blackbody source confirmed the manufacturer's temperature calibration over the range of $300^{\circ} \mathrm{C}$ to $800^{\circ} \mathrm{C}$. The IR video was also calibrated at lower temperatures with the hotplate before, during, and at the end of the drilling tests. The hotplate temperature was measured with a Type $K$ surface thermocouple, which was calibrated to within $1^{\circ} \mathrm{C}$ in ice water and in boiling water. The test coupons (steel plates and drum lids) were placed on the hotplate, and the IR video calculated the temperature using various emissivity settings. Readings were taken at temperatures ranging from room temperature to $400^{\circ} \mathrm{C}$. The emissivity setting that agreed best with the surface thermocouple reading throughout the temperature range was the setting used for later observations of the drilling procedure. The best-fit emissivity of the $t-i n$. steel plates was -0.8 and that of the 16-gauge steel

\footnotetext{
${ }^{2}$ Probeye is a trademark of Hughes Aircraft Company.
} 
drum lids was 0.2 . The emissivity of the drum lid was lower than that of the carbon steel plate because the drum lid was shinier and more reflective. The emissivity of the TiN drill bit could not be measured by this method.

During the calibration and testing, the IR video temperature scale was found to be nonlinear. At the high end of the range, the IR temperature measurements were accurate. At the low end of the range, the IR video reading was higher than the actual temperature. The wider the temperature range, the greater the error in temperature in the lower end of the temperature range. The result of this nonlinearity was that the initial IR video temperature reading at the start of the drilling procedure was higher than the actual room temperature. However, and more importantly, the maximum temperatures (at the upper part of the temperature range) measured by the IR video during the drilling procedure were much more accurate. For example, if the reading was at the upper part of the temperature range of the video system, the temperature would be uncertain by about $\pm 20^{\circ} \mathrm{C}$ at $200^{\circ} \mathrm{C}$ for a $20 \%$ uncertainty in the emissivity value.

Furthermore, during the course of the project, it was discovered that the focusing mechanism of the IR video camera was inoperable. The result was that the earlier video images (Tests 15 through 78, Appendix B) were not in sharp focus. At the 1-m observation distance used for these measurements, this blurred image resulted in the averaging of the temperature over an approximately 4-cm-diameter area. The later observations (Tests 79 through 93. Appendix B) were made at a closer $(0.3-\mathrm{m})$ observation distance. The IR video camera was in sharp focus at this distance and its spatial resolution has slightly better than $1 \mathrm{~mm}$.

\subsection{EXPERIMENTAL PROCEDURES}

At the start of the test, the 8-L chamber was evacuated, and then the flammable gas and air were added at the partial pressures required to give the desired mixture composition at the desired test pressure. The two flammable gases tested were hydrogen $\left(\mathrm{H}_{2}\right)$ and methane $\left(\mathrm{CH}_{4}\right)$. Based on the precision of the pressure transducers used for monitoring the addition of gases by partial pressures, the precision of the gas mixture compositions ranged from $\pm 0.2 \%$ at $10.0 \%$ to $\pm 0.5 \%$ at $30.0 \%$. The internal fan was used to mix the gases. During mixing tests in a 120-L chamber for the earlier Hanford Site research (Cashdollar et al. 1992), there was essentially no difference in the measured $\mathrm{H}_{2}$ concentrations from the start to the end of the fan mixing time period (5 min). This showed that the gases were well mixed (even before the fan was turned on). Nevertheless, to be cautious, the gases in the 8-L chamber were mixed by the fan for at least 2 min before each test. The fan was turned off before the flammability or drilling tests.

For tests conducted at an elevated initial temperature, the $8-\mathrm{L}$ chamber was wrapped with electrical heater tape, and the internal gas temperature was measured with the $320 \mu \mathrm{m}$ thermocouple. The IR video was used to confirm that the test coupon was also heated to the required initial temperature before starting the test.

Before the drilling tests were conducted, flammable mixtures of $\mathrm{H}_{2}$-air or $\mathrm{CH}_{4}$-air were ignited in the 8-L chamber to determine the maximum exptosion 
pressure generated. For these flammability tests, an electric spark ignited the gas mixture, and the maximum explosion pressure was measured by the pressure transducers. These flammability tests were conducted both with the 8-L chamber entirely closed and with a 5/16-in. vent hole in the chamber top. For the vented tests, the vent hole was covered with masking tape while the chamber was evacuated and the gases were added.

During a drilling test, the drill bit would puncture the test coupon and enter the 8-L chamber that was filled with a flammable gas mixture. The pressure transducers would measure any pressure rise if the gas would ignite. If the gas did not ignite, the pressure would drop slightly as the drill bit punctured the test coupon because the initial chamber pressure was slightly above local atmospheric pressure. The regular video camera would record any flame exiting the chamber through the drill hole if the gas would ignite. The IR video system was used to record the temperatures of the drill bit and test coupon during the drillin's process.

The standard cycle for the drill operation consisted of several steps. First, a solenoid valve opened to allow pressurized gas to enter the pneumatic drill. The standard working pressure of the drill was 6.2 bar ( $90 \mathrm{psi}$ ). This pressure was measured close to the point at which the gas entered the drill. As the drill was pressurized, the bit would rotate and advance at rates related to the pressure. At a pressure of 6.2 bar (90 psi), the rotational speed was $-640 \mathrm{rpm}$ and the advance rate was $-13 \mathrm{~cm} / \mathrm{min}(5.1 \mathrm{in} . / \mathrm{min})$. In the standard cycle of the drill, it would advanced about 2 to $3 \mathrm{~cm}$ ( -1 in.) in about 10 to $15 \mathrm{~s}$. Then it would automatically return to its starting position and stop.

\subsection{FLAMMABILITY AND IGNITABILITY OF HYDROGEN ANC METHANE IN AIR}

Hydrogen in air is flammable over the range from $4 \%$ to $75 \% \mathrm{H}_{2}$, and the stoichiometric value is $29.5 \% \mathrm{H}_{2}$ (Cashdollar et al. 1992, Kuchta 1985, Zabetakis 1965). The maximum measured explosion pressure and the maximum calculated adiabatic temperature are found at $30 \% \mathrm{H}_{2}$ (Cashdollar et al. 1992). Methane in air is flammable over the range from 5 to $_{2} 15 \% \mathrm{CH}_{4}$, and the stoichiometric value is $9.4 \% \mathrm{CH}_{4}$ (Kuchta 1985 and Zabetakis 1965). The maximum measured explosion pressure and the maximum calculated adiabatic temperature are found at $10 \% \mathrm{CH}_{4}$ (Cashdollar et al. 1992). Near-

stoichiometric mixtures of $\mathrm{H}_{2}$-air or $\mathrm{CH}_{4}$-ir are easily ignited with an electric spark. The spark ignition energy of $\mathrm{H}_{2}$-air is relatively independent of gas concentration near the stoichiometric value (Lewis 1951). The minimum ignition energy (Kuchta 1985) of $\mathrm{H}_{2}$-air is $0.02 \mathrm{~mJ}$, and the minimum ignition energy of $\mathrm{CH}_{4}$-air is $0.3 \mathrm{~mJ}$. (The minimum ignition energies of other gases and vapors are listed in Table 13 [Kuchta 1985].) The autoignition temperature of $\mathrm{H}_{2}$-air is $500^{\circ} \mathrm{C}$ to $520^{\circ} \mathrm{C}$ and the autoignition temperature of $\mathrm{CH}_{6}$-air is $600^{\circ} \mathrm{C}$ to $630^{\circ} \mathrm{C}$ (Conti 1988, De Soete 1975, and Kuchta 1985). (The autoignition temperatures of other gases and vapors are listed in Table 15 [Kuchta 1985].) The autoignition temperatures of $\mathrm{H}_{2}$ and $\mathrm{CH}_{4}$ are relatively independent of gas concentration near the stoichiometric values (Conti 1988). The autoignition temperatures were measured in closed-volume chambers (Conti 1988, De Soete 1975, and Kuchta 1985) with all walls uniformly heated so that there was a large area of contact with the gas and the entire 
gas volume would be heated to the test temperature. The minimum ignition temperatures are much higher if the heated area is much smaller and only part of the gas volume is heated. For example, the ignition temperature of $\mathrm{H}_{2}$-air was $750{ }^{\circ} \mathrm{C}$ and that for $\mathrm{CH}_{4}$-air was $1,220{ }^{\circ} \mathrm{C}$ when they were heated by a 1-mm-diameter Nichrome ${ }^{3}$ ire (Kuchta 1985).

\subsection{EXPERIMENTAL DATA}

\subsection{FLAMABILITY TESTS IN CLOSED OR VENTED CHAMBER}

The detailed data for the flammability tests are listed in Appendix A. The mixtures of $\mathrm{H}_{2}$ in air or $\mathrm{CH}_{4}$ in air were ignited with an electric spark in the 8-L chamber. The date and run number are listed in columns one and two. The percentage and type of flammable gas are listed in columns three and four. The percentage of air in the chamber is listed in column five. The initial chamber pressure (absolute) and maximum explosion pressure (absolute) are listed in columns six and seven, respectively. To determine the explosion pressure rise for each test, subtract the value in column six from the value in column seven. The explosion pressure ratio listed in column eight is the maximum explosion pressure divided by the starting pressure. Because the starting pressure is approximately 1 bar or $1 \mathrm{~atm}$, the pressure ratio is approximately the absolute explosion pressure in bars or atmospheres. The last column lists the initial chamber test temperature.

As part of the gas flammability tests, the maximum pressures and rates of pressure rise were measured for both the constant volume and vented cases. The vent hole had a diameter of $5 / 16$ in. (the size of the standard TiN drill bit). The stoichiometric $\mathrm{H}_{2}$-air mixtures burned so fast that the maximum pressure for the vented explosions was only slightly less than that for the closed-volume tests. The average maximum pressure for the vented $\mathrm{CH}_{4}$-air explosions was " 1 bar lower than for the closed-volume tests. The explanation is that stoichiometric $\mathrm{CH}_{4}$-air burns more slowly than stoichiometric $\mathrm{H}_{2}$-air, and the small vent had more time to be effective in reducing the pressure. For both the $\mathrm{H}_{2}$-air and $\mathrm{CH}_{4}$-air in the 8-L chamber, the maximum explosion pressures for the constant volume tests were lower than those measured previously (Cashdollar et al. 1992) in the 120-L chamber because the larger, spherical chamber was more adiabatic.

\subsection{DRILLING TESTS}

The detailed data from the drilling tests are listed in Appendix $B$. The first six columns are the same as in Appendix $A$. The seventh column 1 ists the initial chamber test temperature. The drill bit type and serial number are listed in column eight. The standard 5/16-in.-diameter titanium nitride drill bit is denoted as TiN. The test coupon type and serial number are listed in column nine. The 16-gauge drum lids are denoted as DL, and the - in. carbon steel plates are denoted as CS. The pneumatic drill feed pressure is 1 isted in column ten. The maximum temperature of the test coupon and drill bit, as

\footnotetext{
${ }^{3}$ Nichrome is a trademark of National Westminister Bank, U.S.A.
} 
measured by the IR video camera, is listed in column eleven. This temperature was measured from a frame-by-frame analysis of the video recording. In a few of the tests, the temperature from the video was corrected and/or estimated because the emissivity was set incorrectly for the test or because the maximum temperature was greater than the range on the IR video monitor.

The test conditions that were varied during this drill ignitability project included the following:

- Test coupon type

- Drill feed pressure

- Initial chamber pressure

- Initial chamber temperature

- Flammable gas $\left(\mathrm{H}_{2}\right.$ or $\left.\mathrm{CH}_{4}\right)$

- Drill bit type and size.

The standard drill bit for these tests and for the Hanford CVS was the 5/16-in.-diameter TiN coated bit. For several tests, a worn TiN drill bit was used. As noted in Appendix B, this worn bit was used 50 times to drill through a $\neq$-in.-thick carbon steel plate before using it for the ignitability tests (43 through 45). Also tested were a 5/16-in.-diameter standard steel bit and a

There were no ignitions of stoichiometric $\mathrm{H}_{2}$-air mixtures during a total of 42 tests under any of the test conditions. A few tests were made with stoichiometric $\mathrm{CH}_{4}$-air instead of $\mathrm{H}_{2}$-air mixtures, and there were no ignitions of the $\mathrm{CH}_{4}$ either.

As observed in the regular video for many of the tests, the drill bit tip wandered around on the surface of the test coupon before cutting into the surface because it was not center punched. In several cases, the center of the hole was as much as one-bit-diameter (5/16-in.) off from the center of the test coupon. This would cause some horizontal stress on the bit.

During one of the tests (40, Appendix B), a standard steel bit broke before it punctured the $t-i n$. carbon steel test coupon. In this test, the bit caught in the plate, and a piece broke off and reinained lodged in the plate. After the piece broke off, the drill began to rotate again and frictional sparks were observed in the regular video. The IR video recorded higher temperatures than for similar tests ( 41 and 42$)$ in which the drill bit did not break.

The temperatures of the drill bits and lids were measured by the IR video system during the drilling tests. Using the standard TiN drill bit, the measured IR temperatures were significantly lower than the $\sim 500{ }^{\circ} \mathrm{C}$ autoignition temperature of $\mathrm{H}_{2}$-air or the $-600^{\circ} \mathrm{C}$ autoignition temperature of $\mathrm{CH}_{4}$-air. For the early tests (6 through 78, Appendix B), the IR video camera was not in sharp focus and, consequently, the temperature was averaged over a 4-cm-diameter area. Under this condition, the average maximum IR temperature for a total of 26 tests, while drilling through the $-i n$. carbon steel plates, was $109{ }^{\circ} \mathrm{C}\left( \pm 11^{\circ} \mathrm{C}\right)$ at drill feed pressures of 6.2 to 7.6 bar (90 to $110 \mathrm{psi}$ ). During these tests, the maximum temperature lasted for about $5 \mathrm{~s}$ while drilling through a steel plate. In the standard tests, the IR video system observed the test coupon from above at an angle of about 45 degrees from the horizontal. To see if the temperature would be higher on the bottom of the 
test coupon as the bit punctured it, some tests were made with the test coupon held in a bench vise with the IR video camera observing from the bottom. In these tests (61 through 64), the average maximum temperature was somewhat higher $\left(136{ }^{\circ} \mathrm{C}\right)$. For the 16 -gauge steel drum lids viewed from above, the average maximum IR temperature was $141^{\circ} \mathrm{C}\left( \pm 30^{\circ} \mathrm{C}\right)$ for a total of 13 tests at a drill feed pressure of 6.2 bar $(90 \mathrm{psi}$ ). During these tests, the maximum temperature lasted for about 2 to $3 \mathrm{~s}$ while drilling through a drum 1 id.

There was no significant difference in measured temperatures while drilling with the 5/16-in.-diameter steel bit. The measured temperatures were significantly higher, however, when using the $f$-in.-diameter carbide tipped steel bit (Tests 55 through 59 and 77 and 78, Appendix B). The reason for this is probably that the larger diameter results in a larger area of frictional contact between the bit and the plate or drum lid. In addition, the linear velocity at the periphery of the bit tip would be higher for the larger diameter bit at the same rotational speed. An additional problem with the 1 -in.-diameter bit was that it deformed the drum lids while drilling, producing a concave surface. Therefore, it would not be advisable to use larger drill bits in the CVS.

For the later tests ( 79 through 93, Appendix B), the IR video camera was in sharp focus, and the spatial resolution of the temperature measurements was better than $1 \mathrm{~mm}$. Under this condition, the maximum measured temperatures were considerably higher but confined to much smaller areas. The average maximum IR temperature for six tests while drilling through the $-i n$. carbon steel plates was $245{ }^{\circ} \mathrm{C}\left( \pm 13^{\circ} \mathrm{C}\right)$ at drill feed pressures of 6.2 to 7.6 bar (90 to $110 \mathrm{psi}$ ). The average maximum IR temperatures while drilling through the 16-gauge drum 1 ids were $353^{\circ} \mathrm{C}\left( \pm 9^{\circ} \mathrm{C}\right)$ for three tests at a drill feed pressure of $6.2(90 \mathrm{psi})$ and $388{ }^{\circ} \mathrm{C}\left( \pm 10^{\circ} \mathrm{C}\right)$ for three tests at a drill feed pressure of 7.6 (110 psi). From the IR video recordings, it appeared that the hottest objects observed while drilling into the steel plates were drill shavings, and they may have had emissivities lower than the value of 0.8 used for the oxidized surface of the plate. If this was so, the true maximum temperatures for the steel plate tests may have been higher, closer to those measured for the drum lid tests. These temperatures measured with the IR video camera in sharp focus are most appropriately compared with the ignition temperatures obtained using the 1-mm-diameter, heated Nichrome wire (Kuchta 1985), as described in Section 4.0. For thermal ignition by a small contact area, the ignition temperature of $\mathrm{H}_{2}$-air was $750^{\circ} \mathrm{C}$ and that of methane-air was $1,220^{\circ} \mathrm{C}$ when they were heated by the 1-mm-diameter Nichrome wire. Again, the measured temperatures (Appendix B) during the drilling process were significantly lower than these gas ignition temperatures. 


\subsection{CONCLUSIONS}

There were no ignitions of either stoichiometric $\mathrm{H}_{2}$-air or $\mathrm{CH}_{4}$-air mixtures during the drilling tests. The temperatures of the dri11 bits and lids were measured by an IR video system during the drilling tests and found to be significantly lower than the $-500{ }^{\circ} \mathrm{C}$ autoignition temperature of $\mathrm{H}_{2}-\mathrm{air}$ or the $-600{ }^{\circ} \mathrm{C}$ autoignition temperature of $\mathrm{CH}_{4}$-air. Although there were no ignitions of the flammable gas mixtures during these drilling tests, it is recommended that the CVS be operated remotely. Note that these conclusions refer only to the specified conditions of tests and may not include all possible safety considerations for the operation of the CVS. This report should be used along with other engineering studies as part of the overall safety evaluation of the CVS.

\subsection{REFERENCES}

Cashdollar, K. L., M. Hertzberg, I. A. Zlochower, C. E. Lucci, G. M. Green, and R. A. Thomas, 1992, Laboratory Flammability Studies of Mixtures of Hydrogen, Nitrous Oxide, and Air, WHC-SD-WM-ES-219, Westinghouse Hanford Company, Richland, Washington.

Conti, R. S., and M. Hertzberg, 1988, "Thermal Autoignition Temperatures for Hydrogen-Air and Methane-Air Mixtures," Journal of Fire Sciences, Vol. 6, pp. 348-355.

DeSoete, G. G., 1975, The Flammability of Hydrogen-Oxygen-Nitrogen Mixtures at High Temperatures, La Rivista dei Combustibility, Vol. 29, pp. 166-172.

Kuchta, J. M., 1985, Investigation of Fire and Explosion Accidents in the Chemical, Mining, and Fuel-Related Industries - A Manual, BuMines B.680, U.S. Department of the Interior, Pittsburg, Pennsylvania.

Lewis, B., and G. von Elbe, 1951, Combustion, Flames, and Explosions of Gases, Academic Press, p. 414.

Zabetakis, M. G., 1965, Flammability Characteristics of Combustible Gases and Vapors," BuMines B. 625, U.S. Department of the Interior, Pittsburg, Pennsylvania. 
WHC-EP-0686

Appendix A

Flammability Tests in 8-Liter Chamber, With Electric Spark Ignition.

\begin{tabular}{|c|c|c|c|c|c|c|c|c|}
\hline Date & Run & $\underset{x}{\operatorname{cas}}$ & $\begin{array}{l}\text { Gas } \\
\text { Type }\end{array}$ & $\operatorname{Air}_{x}$ & $P_{\text {initipl }}$ & $P_{\text {part }}$ & $\begin{array}{l}\text { Pressure } \\
\text { Retio }\end{array}$ & $\begin{array}{l}\text { Chamber } \\
\text { Temp, "C }\end{array}$ \\
\hline \multicolumn{9}{|c|}{ Electric Spark Ignition of Hydrogen-Air in Closed Chember } \\
\hline \multirow[t]{4}{*}{$11 / 16 / 92$} & 1 & 21.0 & $\mathrm{H}_{2}$ & 79.0 & 15.0 & 9.6 & 6.64 & -20 \\
\hline & 2 & 20.0 & $\mathrm{H}_{2}$ & 80.0 & 15.0 & 95.3 & 6.35 & -20 \\
\hline & 3 & 30.0 & $\mathrm{H}_{2}$ & 70.0 & 15.0 & 111.6 & 7.44 & -20 \\
\hline & 4 & 30.0 & $\mathrm{H}_{2}$ & 70.0 & 15.0 & 110.2 & 7.35 & -20 \\
\hline $11 / 47 / 92$ & 5 & 29.8 & $\mathrm{H}_{2}$ & 70.2 & 15.1 & 111.5 & 7.38 & -20 \\
\hline \multicolumn{9}{|c|}{ Electric Spark Ignition of Hydrogen-Air in Chamber with 5/16" Vent Hole } \\
\hline \multirow[t]{7}{*}{$11 / 18 / 92$} & 8 & 29.7 & $\mathrm{H}_{2}$ & 70.3 & 15.1 & 110.9 & 7.33 & -20 \\
\hline & 9 & 30.0 & $\mathrm{H}_{2}$ & 70.0 & 15.0 & 109.7 & 7.32 & -20 \\
\hline & 10 & 30.1 & $\mathrm{H}_{2}$ & 69.9 & 15.0 & 107.6 & 7.19 & -20 \\
\hline & 11 & 30.0 & $H_{2}$ & 70.0 & 15.0 & 108.7 & 7.25 & -20 \\
\hline & 12 & 30.1 & $\mathrm{H}_{2}$ & 69.9 & 14.9 & 107.7 & 7.21 & -20 \\
\hline & 13 & 30.2 & $\mathrm{H}_{2}$ & 69.8 & 14.9 & 106.5 & 7.15 & -20 \\
\hline & 14 & 30.0 & $\mathrm{H}_{2}$ & 70.0 & 15.0 & 108.1 & 7.21 & -20 \\
\hline \multicolumn{9}{|c|}{ Electric Spark Ionition of $\mathrm{CH}_{4}$-Air in Chamber with 5/16" Vent Hole } \\
\hline $12 / 17 / 92$ & 46 & 9.9 & $\mathrm{CH}_{4}$ & 90.1 & 15.2 & 85.4 & 5.62 & -40 \\
\hline \multirow[t]{2}{*}{$12 / 18 / 92$} & 47 & 9.9 & $\mathrm{CH}_{4}$ & 90.1 & 15.1 & 95.7 & 6.35 & -40 \\
\hline & 48 & 9.9 & $\mathrm{CH}_{4}$ & 90.1 & 15.2 & 99.0 & 6.51 & -40 \\
\hline $12 / 22 / 92$ & 49 & 10.0 & $\mathrm{CH}_{4}$ & 90.0 & 15.0 & 99.9 & 6.66 & -22 \\
\hline \multicolumn{9}{|c|}{ Electric Spark Ignition of $\mathrm{CH}_{4}-\mathrm{Air}$ in Closed Chamber } \\
\hline $12 / 22 / 92$ & 50 & 10.0 & $\mathrm{CH}_{4}$ & 90.0 & 14.9 & 109.8 & 7.35 & -22 \\
\hline & 51 & 10.0 & $\mathrm{CH}_{4}$ & 90.0 & 15.0 & 108.8 & 7.25 & -22 \\
\hline
\end{tabular}


WHC-EP-0686

Appendix B

Tests of Drilling Into 8-Liter Chamber Containing Flammable Gas.

\begin{tabular}{|c|c|c|c|c|c|c|c|c|c|c|}
\hline Date & Run & $\operatorname{cas}_{x}$ & $\begin{array}{l}\text { Gas } \\
\text { Type }\end{array}$ & $\operatorname{Air}_{x}$ & $P_{\text {ingitiol }}$ & $\begin{array}{l}\text { Chamber } \\
\text { reap. "C }\end{array}$ & $\begin{array}{c}\text { Drill } \\
\text { Bit }\end{array}$ & $\begin{array}{l}\text { Test } \\
\text { Coupon }\end{array}$ & $\begin{array}{c}\text { Drill } \\
\text { Pressure, } \\
\text { pei }\end{array}$ & ${ }^{\top} \operatorname{eqx}$ \\
\hline \multicolumn{11}{|c|}{ Drilling Test, Chamber filled with Air } \\
\hline \multirow[t]{2}{*}{$11 / 17 / 92$} & 6 & 0.0 & & 100.0 & 15.2 & -20 & $T H-1$ & $\operatorname{cs}-1$ & 90 & \\
\hline & 7 & 0.0 & & 100.0 & 40.1 & -20 & TiN-1 & CS-2 & 90 & \\
\hline \multicolumn{11}{|c|}{ standard Orilling rests, Chanber Filled with $\mathrm{H}_{2}-A i r$} \\
\hline \multirow[t]{2}{*}{$11 / 20 / 92$} & 15 & 39.8 & $\mathrm{H}_{2}$ & 60.2 & 12.1 & -20 & TiN-1 & cs-3 & 90 & 118 \\
\hline & 16 & 30.0 & $\mathrm{H}_{2}$ & 70.0 & 16.0 & -20 & TIN-1 & CS-4 & 90 & 73 \\
\hline \multirow[t]{4}{*}{$11 / 24 / 92$} & 17 & 29.3 & $\mathrm{H}_{2}$ & 70.7 & 16.4 & -20 & Tin-1 & Cs-5 & 90 & 114 \\
\hline & 18 & 29.9 & $M_{2}$ & 70.1 & 16.0 & -20 & rin-1 & Cs-6 & 90 & 111 \\
\hline & 19 & 30.0 & $\mathrm{H}_{2}$ & 70.0 & 16.0 & -20 & TiN-1 & CS-7 & 90 & 116 \\
\hline & 20 & 30.1 & $\mathrm{H}_{2}$ & 69.9 & 15.9 & -20 & TiN-1 & CS-8 & 90 & 89 \\
\hline \multirow[t]{4}{*}{$12 / 02 / 92$} & 21 & 29.8 & $\mathrm{H}_{2}$ & 70.2 & 16.3 & -20 & TiN-1 & $D L-1$ & 90 & -110 \\
\hline & 22 & 29.8 & $\mathrm{H}_{2}$ & 70.2 & 16.1 & -20 & TiN-1 & CS-9 & 40 & 105 \\
\hline & 23 & 29.8 & $\mathrm{H}_{2}$ & 70.2 & 16.1 & -20 & TiN-1 & $\operatorname{cs}-10$ & 40 & 94 \\
\hline & 26 & 30.3 & $\mathrm{H}_{2}$ & 69.7 & 15.9 & -20 & TIN-1 & $\operatorname{cs}-11$ & 40 & 99 \\
\hline \multicolumn{11}{|c|}{ Orilling Tests, Elevated Initial Preseure, Chamber filled with $\mathrm{H}_{2}$-Air } \\
\hline \multirow[t]{3}{*}{$12 / 03 / 92$} & 25 & 30.0 & $H_{2}$ & 70.0 & 25.0 & -20 & TiN-1 & cs-12 & 90 & 102 \\
\hline & 26 & 30.6 & $\mathrm{H}_{2}$ & 69.6 & 26.7 & -20 & TIH- & Cs-13 & 90 & 104 \\
\hline & 27 & 30.1 & $\mathrm{H}_{2}$ & 69.9 & 24.9 & -20 & TIN-1 & CS-16 & 90 & $\cdots$ \\
\hline \multicolumn{11}{|c|}{ Drilling Tests, E } \\
\hline \multirow[t]{3}{*}{$12 / 07 / 92$} & 28 & 30.0 & $\mathrm{H}_{2}$ & 70.0 & 16.0 & -38 & $T I N-1$ & Cs-15 & 90 & 110 \\
\hline & 29 & 29.9 & $\mathrm{H}_{2}$ & 70.1 & 16.1 & -38 & TiN-1 & cs-16 & 90 & 106 \\
\hline & 30 & 30.2 & $\mathrm{H}_{2}$ & 69.8 & 15.9 & -38 & $T I N-1$ & Cs-17 & 90 & 116 \\
\hline
\end{tabular}




\begin{tabular}{|c|c|c|c|c|c|c|c|c|c|c|}
\hline Date & Run & $\operatorname{Gas}$ & Gas & Air & Pinitiple & Chember & Drill & $\begin{array}{l}\text { Test } \\
\text { Coupon }\end{array}$ & $\begin{array}{l}\text { Drill } \\
\text { Pressure, } \\
\text { pail }\end{array}$ & $T^{T}$ \\
\hline \multicolumn{11}{|c|}{ Stenderd Drilling Tests, Chember Filled with $\mathrm{H}_{2}$-Air } \\
\hline \multirow[t]{3}{*}{$12 / 08 / 92$} & 31 & 30.1 & $\mathrm{H}_{2}$ & 69.9 & 16.1 & -20 & TiN-1 & $D L-2$ & 90 & -98 \\
\hline & 32 & 29.9 & $\mathrm{H}_{2}$ & 70.1 & 16.0 & -20 & TIN-1 & DL-3 & 90 & -93 \\
\hline & 33 & 30.0 & $\mathrm{H}_{2}$ & 70.0 & 16.0 & -20 & $T I N-1$ & $D L-4$ & 90 & -101 \\
\hline \multicolumn{11}{|c|}{ Drilling Tests, Elevated Initiol Teaperature, Chember Filled with $\mathrm{H}_{2}$-Air } \\
\hline \multirow[t]{3}{*}{$12 / 09 / 92$} & 34 & 29.4 & $\mathrm{H}_{2}$ & 70.6 & 16.3 & -40 & Tin-1 & CS-18 & 110 & 113 \\
\hline & 35 & 29.8 & $H_{2}$ & 70.2 & 16.1 & -40 & rin-1 & $\operatorname{cs}-19$ & 110 & 122 \\
\hline & 36 & 29.8 & $H_{2}$ & 70.2 & 16.1 & -40 & IIN-1 & $\operatorname{cs}-20$ & 110 & 123 \\
\hline \multicolumn{11}{|c|}{ Stenderd Drilling Tests, Chember Filled With $\mathrm{H}_{2}$-Air } \\
\hline $12 / 15 / 92$ & 37 & 30.0 & $\mathrm{H}_{2}$ & 70.0 & 16.0 & -23 & Tin-1 & Cs-21 & 110 & -95 \\
\hline \multicolumn{11}{|c|}{ Drilline Tests, Elevated Initial Temperature, Chember Filled with $\mathrm{H}_{2}$-Air } \\
\hline \multirow[t]{2}{*}{$12 / 16 / 92$} & 38 & 30.1 & $\mathrm{H}_{2}$ & 69.9 & 15.9 & -38 & $T I N-2$ & $\operatorname{cs}-22$ & 110 & 107 \\
\hline & 39 & 30.2 & $\mathrm{H}_{2}$ & 69.8 & 15.9 & 38 & TIN-2 & $\operatorname{cs} \cdot 23$ & 110 & 108 \\
\hline \multicolumn{11}{|c|}{ Drilling Teste, Elevoted Initial Temperature, Chember with $\mathrm{H}_{2}$-Air, steel Bits } \\
\hline \multirow[t]{4}{*}{$12 / 16 / 92$} & 40 & 30.1 & $\mathrm{H}_{2}$ & 69.9 & 16.0 & -38 & $\begin{array}{l}5 / 16^{n} \\
\text { steel }\end{array}$ & $\operatorname{cs}-24$ & 110 & $>150^{\circ}$ \\
\hline & 41 & 29.7 & $\mathrm{H}_{2}$ & 70.3 & 16.1 & -38 & $\begin{array}{l}5 / 16^{n} \\
\text { steel }\end{array}$ & $\operatorname{cs}-25$ & 90 & 100 \\
\hline & 42 & 30.1 & $\mathrm{H}_{2}$ & 69.9 & 15.9 & -30 & $\begin{array}{l}5 / 16 n \\
\text { eteel }\end{array}$ & $\operatorname{cs}-26$ & 110 & 103 \\
\hline & \multicolumn{10}{|c|}{$\begin{array}{l}\text { Drilling Teets, Eleveted Initial Temperature, Chember filled with } \mathrm{H}_{2} \text {-Air, } \\
\text { Till Bit Mo. 1, After Drilling - Totel of } 50 \text { rimes Through } 1 / 4 \mathrm{~m} \text { steef Plote }\end{array}$} \\
\hline \multirow[t]{3}{*}{$12 / 17 / 92$} & 43 & 29.9 & $\mathrm{H}_{2}$ & 70.1 & 16.1 & -40 & TIN-1 & Cs-27 & 110 & 108 \\
\hline & 44 & 29.8 & $\mathrm{H}_{2}$ & 70.2 & 16.1 & -40 & TIN-1 & Cs-28 & 110 & 125 \\
\hline & 45 & 29.8 & $\mathrm{H}_{2}$ & 70.2 & 16.1 & -60 & TIN-1 & $\operatorname{cs}-29$ & 110 & 115 \\
\hline
\end{tabular}


WHC-EP-0686

\begin{tabular}{|c|c|c|c|c|c|c|c|c|c|c|}
\hline Dote & Run & $\operatorname{Gas}$ & Gas & $\operatorname{Air}$ & Pinjtipl" & Chember & $\underset{\text { Bit }}{\text { Drill }}$ & $\begin{array}{l}\text { Test } \\
\text { Coupon }\end{array}$ & $\begin{array}{c}\text { Drill } \\
\text { Pressure, } \\
\text { pai }\end{array}$ & $\operatorname{Teq}^{\cos }$ \\
\hline \multicolumn{11}{|c|}{ Drilling Tests, Elevated Initial Temperature, Chember filled with $\mathrm{CH}_{4}$-Air } \\
\hline $12 / 22 / 92$ & 52 & 10.2 & $\mathrm{CH}_{4}$ & 89.8 & 23.6 & -40 & TIN-2 & Cs-30 & 110 & 98 \\
\hline & 53 & 10.0 & $\mathrm{CH}_{4}$ & 90.0 & 16.0 & -40 & TIN-2 & Cs-31 & 110 & 111 \\
\hline & 54 & 10.0 & $\mathrm{CH}_{4}$ & 90.0 & 16.0 & -40 & TIN-2 & CS-32 & 110 & 108 \\
\hline \multicolumn{11}{|c|}{ Drilling Tests, 1/2" Carbide Tipped steel Bit, Chamber Filled with $\mathrm{H}_{2}$-Air } \\
\hline $12 / 29 / 92$ & 55 & 29.8 & $\mathrm{H}_{2}$ & 70.2 & 16.1 & -20 & $\begin{array}{c}1 / 2^{n} \\
\text { steel }\end{array}$ & Cs-33 & 90 & $>150$ \\
\hline & 56 & 30.1 & $\mathrm{H}_{2}$ & 69.9 & 16.0 & -20 & $\begin{array}{l}1 / 2^{n} \\
\text { steel }\end{array}$ & CS-34 & 90 & -201 \\
\hline & 57 & 30.1 & $\mathrm{H}_{2}$ & 69.9 & 15.9 & -20 & $\begin{array}{c}1 / 2^{n} \\
\text { steel }\end{array}$ & cs-35 & 90 & -207 \\
\hline & 58 & 30.0 & $\mathrm{H}_{2}$ & 70.0 & 16.0 & $" 20$ & $\begin{array}{l}1 / 2^{\mathrm{m}} \\
\text { steel }\end{array}$ & cs-36 & 110 & 244 \\
\hline & 59 & 29.9 & $\mathrm{H}_{2}$ & 70.1 & 16.0 & -20 & $\underset{\text { steel }}{1 / 2^{n}}$ & CS-37 & 110 & 230 \\
\hline \multicolumn{11}{|c|}{ Orilling Tests, TiN Bit, flenee and Lid in Vise, Viewnd from Top side of Lid } \\
\hline $12 / 30 / 92$ & 60 & & & & & -23 & TIN-2 & Cs-38 & 90 & 112 \\
\hline \multicolumn{11}{|c|}{ Drilling rests, Tin Bit, $F$} \\
\hline $12 / 30 / 92$ & 61 & & & & & -23 & iin-2 & $\operatorname{cs-39}$ & 90 & 136 \\
\hline & 62 & & & & & -23 & TiN-2 & $\operatorname{Cs}-40$ & 9 & 133 \\
\hline & 63 & & & & & -23 & $\operatorname{Tin-2}$ & $\operatorname{cs}-41$ & 110 & 140 \\
\hline & 64 & & & & & -23 & $\operatorname{rin}-2$ & $\operatorname{cs}-62$ & 110 & 136 \\
\hline \multicolumn{11}{|c|}{ Orilling Tests, Tik Bit, Flenge and Lid in Vise, Vianed from Top side of Lid } \\
\hline \multirow[t]{6}{*}{$01 / 11 / 93$} & 65 & & & & & -23 & Tin-2 & $D L-5$ & 110 & $\pi$ \\
\hline & 66 & & & & & -23 & TiN-2 & $D L-6$ & 110 & -167 \\
\hline & 67 & & & & & -23 & TIN-2 & $D L \cdot 7$ & 90 & -160 \\
\hline & 68 & & & & & -23 & $\operatorname{Tin}-2$ & $D L-8$ & 90 & -161 \\
\hline & 69 & & & & & -23 & TiN-2 & $O L-9$ & 90 & -164 \\
\hline & 70 & & & & & -23 & $T i N-2$ & $D L-10$ & 90 & -161 \\
\hline
\end{tabular}


WHC-EP-0686

\begin{tabular}{|c|c|c|c|c|c|c|c|c|c|c|}
\hline Date & Run & $\cos$ & $\underset{\text { Type }}{\text { cas }}$ & $\stackrel{\operatorname{Air}}{x}$ & $P_{\text {initifal }}$ & $\underset{\text { Temp. }}{\text { Chember }}$ & $\begin{array}{c}\text { Drill } \\
\text { Bit }\end{array}$ & $\begin{array}{l}\text { Test } \\
\text { Coupon }\end{array}$ & $\begin{array}{c}\text { Drill } \\
\text { Pressure, } \\
\text { pel }\end{array}$ & $\operatorname{T}^{\operatorname{cox}}$ \\
\hline \multirow[t]{2}{*}{$01 / 11 / 93$} & 71 & & & & & -23 & TIN-2 & $\operatorname{cs} \cdot 43$ & $\mathbf{9 0}$ & 118 \\
\hline & 72 & & & & & -23 & TIN-2 & $D L-11$ & 90 & -157 \\
\hline \multicolumn{11}{|c|}{ standard Drilling Tests, Chamb } \\
\hline \multirow[t]{4}{*}{$01 / 14 / 93$} & 73 & 30.0 & $\mathrm{H}_{2}$ & 70.0 & 16.0 & -20 & TiN-2 & $D L-12$ & 90 & -167 \\
\hline & 74 & 28.9 & $\mathrm{H}_{2}$ & 71.1 & 16.6 & -20 & TIN-2 & $D L-13$ & 90 & 169 \\
\hline & $\pi$ & 30.0 & $\mathrm{H}_{2}$ & 70.0 & 16.0 & -20 & Tin-2 & $D L-14$ & $\infty$ & 163 \\
\hline & 76 & 29.9 & $\mathrm{H}_{2}$ & 70.1 & 16.1 & -20 & TIN-2 & $D L-15$ & 90 & -150 \\
\hline \multicolumn{11}{|c|}{ Drilling Teats, 1/2" Corbide Tipped steel Bit, Chember Filled with $\mathrm{H}_{2}$-Air } \\
\hline \multirow[t]{2}{*}{$01 / 14 / 93$} & $\pi$ & 30.2 & $\mathrm{H}_{2}$ & 69.8 & 15.9 & -20 & $\begin{array}{l}1 / 2^{n} \\
\text { steel }\end{array}$ & $D L-16$ & $\boldsymbol{\varphi 0}$ & 164 \\
\hline & 78 & 30.1 & $\mathrm{H}_{2}$ & 69.9 & 15.9 & -20 & $\underset{\text { eteel }}{1 / 2^{n}}$ & $O L-17$ & 90 & -210 \\
\hline \multicolumn{11}{|c|}{ Drilling Teste, 5/16" rin } \\
\hline \multirow[t]{12}{*}{$02 / 04 / 93$} & 79 & & & 100.0 & & -20 & $\operatorname{Tin-2}$ & $\operatorname{cs}-64$ & 90 & 253 \\
\hline & 80 & & & 100.0 & & -20 & TIN-2 & $\operatorname{cs}-45$ & $\boldsymbol{9 0}$ & 227 \\
\hline & 81 & & & 100.0 & & -20 & TIN-2 & Cs-46 & $\boldsymbol{9 0}$ & 259 \\
\hline & 82 & & & 100.0 & & -20 & Tin-2 & $c s-47$ & 110 & 257 \\
\hline & 83 & & & 100.0 & & -20 & TIN-2 & $\operatorname{cs}-48$ & 110 & 243 \\
\hline & 84 & & & 100.0 & & -20 & Tin-2 & $\operatorname{cs}-49$ & 110 & 232 \\
\hline & 85 & & & 100.0 & & -20 & rin-2 & $D L-18$ & 90 & 363 \\
\hline & 86 & & & 100.0 & & -20 & rin-2 & $D L=19$ & 90 & 345 \\
\hline & 87 & & & 100.0 & & -20 & $T I N-2$ & $D L=20$ & $\boldsymbol{\varphi 0}$ & 352 \\
\hline & 88 & & & 100.0 & & -20 & TiN-2 & $D L-21$ & 110 & -400 \\
\hline & 89 & & & 100.0 & & -20 & TIN-2 & $D L-22$ & 110 & 385 \\
\hline & 90 & & & 100.0 & & -20 & rin-2 & $D L-23$ & 110 & 380 \\
\hline
\end{tabular}


WHC-EP-0686

\begin{tabular}{|c|c|c|c|c|c|c|c|c|c|c|}
\hline Date & Run & Ges & Type & Air & Pinitifal" & $\begin{array}{l}\text { Chember } \\
\text { remp, "c }\end{array}$ & Drill & $\begin{array}{l}\text { Teet } \\
\text { coupon }\end{array}$ & $\begin{array}{l}\text { Drill } \\
\text { Preasure, } \\
\text { pei }\end{array}$ & ${ }^{\top} e^{x}$ \\
\hline \multicolumn{11}{|c|}{$\begin{array}{l}\text { Drilling Teets, 1/2" Carbide Tipped steel Bit, Higher Resolution and sharper focus, } \\
\text { Chember filled with Air }\end{array}$} \\
\hline $02 / 05 / 93$ & 91 & & & 100.0 & & -20 & $\begin{array}{l}1 / 2^{n} \\
\text { steel }\end{array}$ & Cs.50 & 90 & 395 \\
\hline & 92 & & & 100.0 & & -20 & $\begin{array}{l}1 / 2 n \\
\text { steel }\end{array}$ & CS-51 & 90 & $>400$ \\
\hline & 93 & & & 100.0 & & -20 & $\begin{array}{l}1 / 2^{\infty} \\
\text { steel }\end{array}$ & $\operatorname{cs}-52$ & 90 & $>400$ \\
\hline
\end{tabular}

*Drill bit broke during Test 40 , before drilling completely through coupon.

Notes: $D L=16$ gauge drum 1id

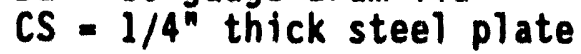


Number of Copies

\section{OFFSITE}

3

U.S. Department of EnergyHeadquarters

19901 Germantown Road

Germantown, Maryland 20874

Gary Deleon

EM-322

Trevion II

Dave Simpson, BDM (1)

3

Idaho National Engineering

Laboratory

Don Pound

EG\&G Idaho

P. O. Box 1625

Idaho Falls, Idaho 83415-2424 MS-2424

2

U.S. Department of the

Interior

K. L. Cashdollar

Bureau of Mines

Pittsburgh Research Center

P. 0. Box 18070

Pittsburgh, Pennsylvania 15236-0070

2

Lawrence Livermore National

Laboratory

William T. Fritts

P. 0. Box 808

Livermore, California 94551

3

Los Alamos National Laboratory

Ed Derr

P. O. Box 1663

$J 595$

Los Alamos, New Mexico 87545 EM-7

Westinghouse Savannah River

4

Leroy Williams

P. 0. Box 616

Building 676-T

Aiken, South Carolina 29802

Distr-1 


\section{ONSIIE}

U.S. Department of EnerayRichland Operations office

D. W. Claussen R3-80

R. M. Gordon R3-80

R. F. Guercia R3-80

Kestinghouse Hanford Company

R. R. Ames

N3-13

D. E. Ball

G6-46

J. A. Demiter (13)

โ5-3!

D. C. Derosa

J. L. Dowel1

H5-33

D. R. Duncan

J. D. Elltot

K. L. Hladek

L5-07

H5-33

T4-06

A. W. Hinkle

N3-13

G6-46

D. M. Johnson

H5-33

J. P. Joyce

H4-68

M. R. Kerns

H5-33

D. R. Kibbe

L4-86

R. L. Mart in

T3-03

E. P. Mertens

N3-13

D. J. Meyers

T3-03

D. K. Harper

H4-16

M. M. McCarthy

N3-13

V. P. Ocampo

W. W. 01 son

G6-47

C. C. Simmons

H4-70

R. J. Roberts

H5-70

N3-13

K. E. Smith

G6-47

J. R. Weidert

G6-46

Central Files

L8-15

Information Release

Administration (3)

L8-07 

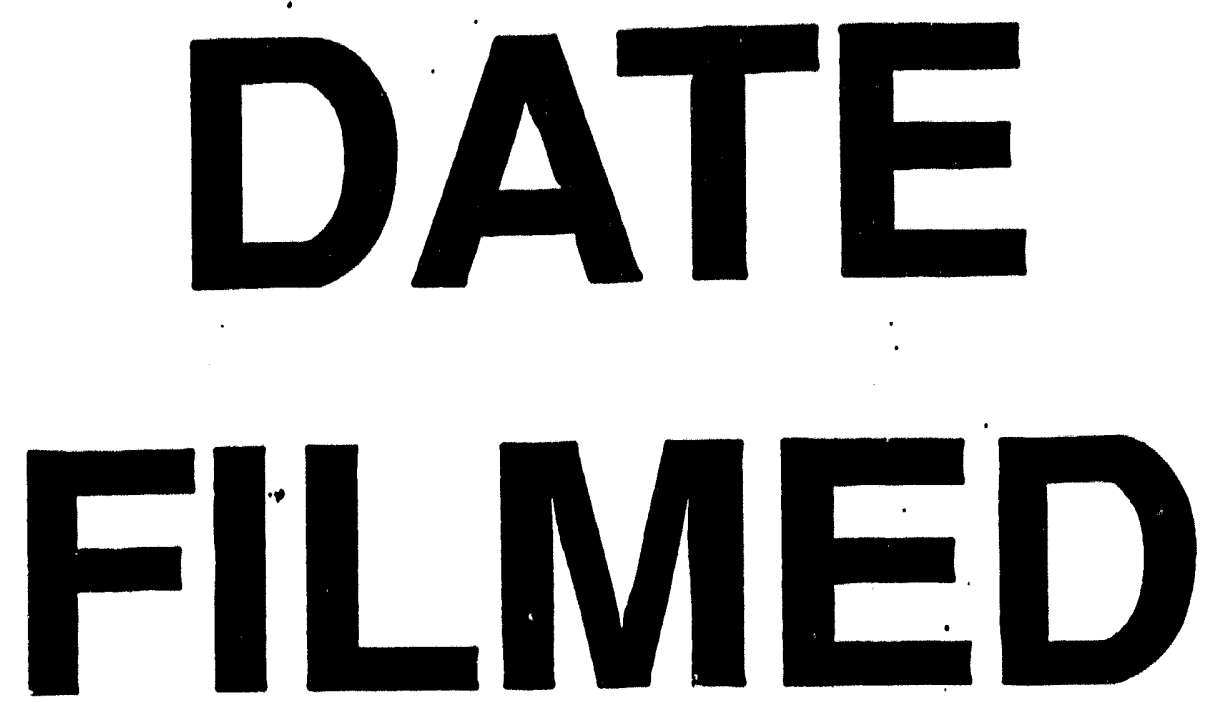

$1 / 11 / 94$
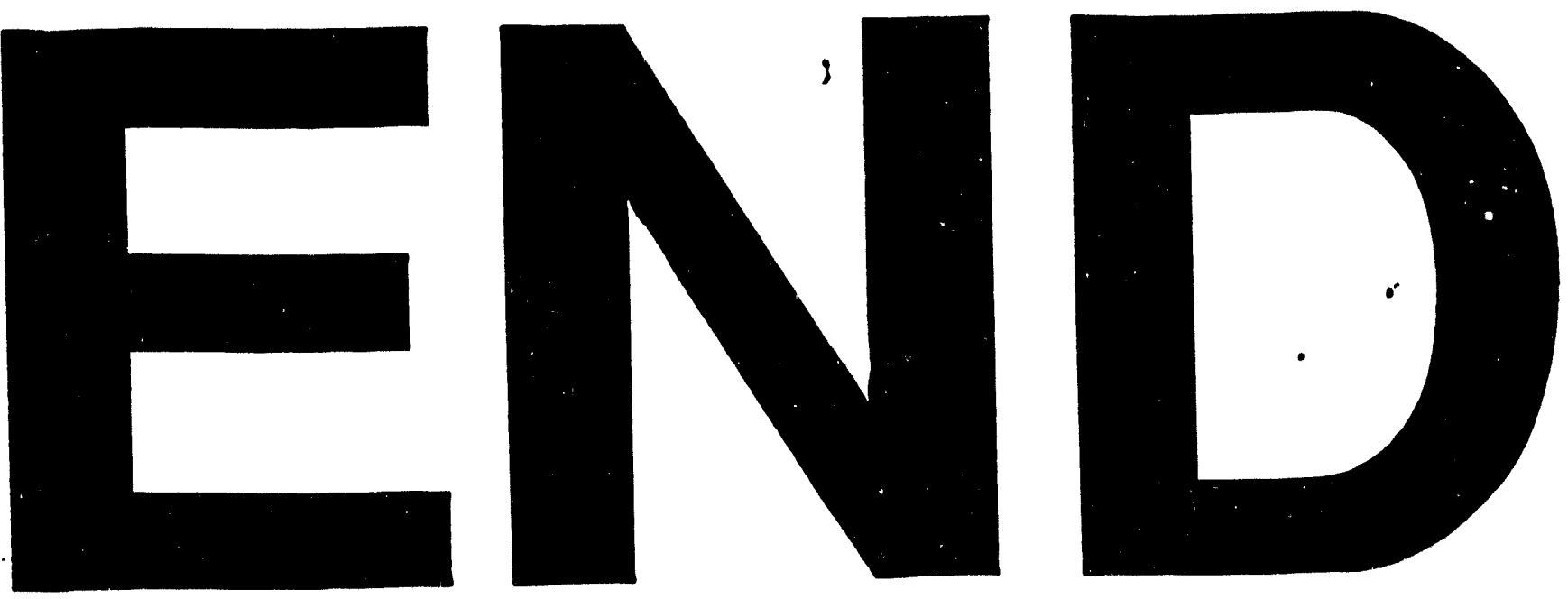